\title{
Effects of a Protein-Rich Diet during Convalescence from Shigellosis on Catch-up Growth, Serum Proteins, and Insulin-Like Growth Factor-I
}

\author{
IQBAL KABIR, THOMAS BUTLER, LOUIS E. UNDERWOOD, AND M. MUJIBUR RAHMAN \\ International Centre of Diarrheal Disease Research, Bangladesh [I.K., M.M.R.]; Department of Internal \\ Medicine, Texas Tech University Health Sciences Center, Lubbock, Texas 79430 [T.B.]; and Department of \\ Pediatrics, University of North Carolina, Chapel Hill, North Carolina 27599 [L.E.U.]
}

\begin{abstract}
Shigellosis in children can cause growth retardation, worsening of malnutrition, and hypoproteinemia. To assess the effects of ingestion of a protein-rich diet during convalescence, 22 children aged 2 to $4 \mathrm{y}$ with culture-proven shigellosis were randomly assigned after 5 d of antibiotic treatment to 21 -d feeding regimens of either a $150 \mathrm{kcal} / \mathrm{kg} / \mathrm{d}$ high-protein diet with $15 \%$ of calories as protein or an isocaloric control diet with $6 \%$ of calories as protein. At the start and end of dietary treatment, weight, height, mid-arm circumference, skinfold thickness, serum protein concentrations, and serum IGF-I were measured. Means of weight gain and increases in mid-arm circumference were greater in children fed high-protein diets than those fed control diets $(1.23$ versus $0.76 \mathrm{~kg} ; 1.40$ versus $0.96 \mathrm{~cm} ; p<0.05$ ). Mean increase in height in children fed high-protein diets $(0.83 \mathrm{~cm})$ was not significantly greater than with control diets $(0.74 \mathrm{~cm})$. Mean increases in serum concentrations of total protein, prealbumin, and retinol-binding protein were greater in the high-protein group than in controls $(p<0.05)$. Mean serum concentrations of IGF-I were low in both groups before treatment $[4.2 \pm 2.6 \mathrm{nmol} / \mathrm{L}(31.9 \pm 19.6 \mathrm{ng} / \mathrm{mL})$ in controls; $3.1 \pm$ $3.4 \mathrm{nmol} / \mathrm{L}(24.0 \pm 26.3 \mathrm{ng} / \mathrm{mL})$ in the high-protein groupl but increased more in the high-protein group $[39.0 \pm 16.2$ $\mathrm{nmol} / \mathrm{L}(298 \pm 124 \mathrm{ng} / \mathrm{mL})]$ than in the control group [16.7 $\pm 9.2 \mathrm{nmol} / \mathrm{L}(128 \pm 70 \mathrm{ng} / \mathrm{mL}), p<0.01]$. These results suggest that high dietary protein is more effective than a normal protein intake in repleting body proteins and in stimulating growth after shigellosis in children. A possible mechanism for this stimulatory effect on growth may be through the restoration of IGF-I. (Pediatr Res 32: 689692, 1992)
\end{abstract}

\section{Abbreviations}

IGFBP, insulin-like growth factor binding protein

Children in developing countries have slower growth rates than children in developed countries, and many are stunted when they reach adulthood. A large part of this growth retardation is caused by malnutrition due to decreased intake of food

Received January 7, 1992; accepted July 31, 1992.

Correspondence and reprint requests: Thomas Butler, M.D., Department of Internal Medicine, Texas Tech University Health Sciences Center, Lubbock, TX 79430.

Supported in part by a grant from the Rockefeller Foundation and by National Institute of Health Research Grant HD 26871. during infectious diseases. Scrimshaw (1) attributed the decreased intake/use of calories during infection to a combination of anorexia, fever, withdrawal of solid food by parents, impaired intestinal absorption, and nutrient losses in body fluids. From a prospective study of the effects of diarrheal infections on growth of children in Bangladesh, Black et al. (2) concluded that shigellosis caused significant retardation of linear growth, and diarrhea due to Escherichia coli caused retardation of weight gain.

The World Health Organization advised continued breastfeeding and feeding of weaning diets during diarrhea (3). These recommendations apply mainly to watery diarrheas affecting the small intestine, and less attention has been given to shigellosis and other infections affecting the colon (4). Furthermore, no recommendations are available regarding feeding during the recovery period.

Catch-up of lost growth is desirable during and after acute infections. Whitehead (5) calculated that a $7-\mathrm{kg}$ child needs $25 \%$ more calories for catch-up growth than for normal growth (about $150 \mathrm{kcal} / \mathrm{kg} / \mathrm{d}$ ), and the percentage of calories supplied as protein needs to be nearly doubled (to more than $11 \%$ ). The duration of intensive feeding needed for growth catch-up was estimated to be about three times longer than the preceding acute disease, because the anabolic phase of recovery is assumed to last three times longer than the catabolic phase of disease (1).

In addition to growth impairment, infections and malnutrition lead to reductions in serum protein concentration. In Bangladesh, serum protein concentrations in children with severe shigellosis are about half of the normal values (6). Diets with higher protein content may have a beneficial effect to increase the rate of albumin synthesis, thus raising the serum albumin and protecting children against symptoms of malnutrition (7).

In the following study, children recovering from acute shigellosis were fed a high-protein diet and were compared with a control group fed an isocaloric diet with less protein. The role of hormonal control of catch-up growth was examined by measuring serum IGF-I, which is a mediator of growth hormone and known to rise in patients after dietary repletion with calories and protein (8).

\section{MATERIALS AND METHODS}

Patient selection and management. Twenty-two children between 2 and 4 y of age with culture-proven Shigella dysentery were the subjects of this study. To be eligible, the patients' respective parents or guardians had to give consent for the patient to remain in the hospital for $26 \mathrm{~d}$ and agree to receive one of the two study diets by randomization. Patients were excluded if they had 3rd-degree malnutrition [body weights less than $60 \%$ of the Harvard Standard of weight for age (9)], nutritional edema, or 
other signs of kwashiorkor. Each patient was treated for $5 \mathrm{~d}$ with nalidixic acid or another antimicrobial chosen on the basis of in vitro sensitivity testing of their Shigella isolates. The standard hospital diet was provided during these $5 \mathrm{~d}$ of treatment.

Randomization and dietary treatments. At the end of the $5 \mathrm{~d}$ of treatment, patients were randomly assigned either to the control or the high-protein diet, using sealed envelopes that contained cards designating diets in an order obtained from a table of random numbers. Both diets were isocaloric and provided a caloric intake of $150 \mathrm{kcal} / \mathrm{kg}$ body weight $/ \mathrm{d}$. The control diet contained approximately $6 \%$ of total calories as protein, whereas the high-protein diet contained $15 \%$ as protein. The bulk of calories in both diet groups was derived from rice and bread. The protein sources consisted mainly of eggs, chicken, and dried skimmed milk. In sample diets, caloric value was determined by Idiabetic bomb calorimetry (Gallenkamp, United Kingdom) and protein content from measurement of nitrogen content by the Kjeldahl method (10). The diets were given in the hospital for $21 \mathrm{~d}$. Nurses recorded portions of food vomited or not eaten.

Protein measurements and data analysis. Before the start of the diets, patients were weighed to the nearest $g$, and height was measured to the nearest $\mathrm{mm}$ on a stand-up scale. Mid-upperarm circumference was measured with a tape, and triceps skinfold thickness with a skin caliper (John Bull, British Indicators, Ltd., United Kingdom). Blood was obtained for determination of serum proteins. The total serum protein was measured by refractometry and the albumin concentration by the biuret method (11). The serum prealbumin and retinol-binding protein were determined by radial immunodiffusion (Boehringer $A G$, Mannheim, Germany). Serum concentrations of IGF-I were measured by RIA, after the IGF-I had been separated from IGFBP by Sep-Pak Chromatography (Waters Associates, Milford, MA) (12). IGF-I values of Bangladeshi patients were compared with those of normal US children of similar age (13). At the end of $21 \mathrm{~d}$ of dietary treatment, the weight and height measurements and determinations of concentration of serum proteins and IGF-I were repeated. Means of the increments of height, weight, and serum protein concentrations between the two dietary groups were compared by a paired $t$ test.

\section{RESULTS}

Characteristics of children before dietary intervention. The 22 children in the two study groups were comparable in regard to male preponderance, species of Shigella infections, and mean weight of stool passed on the first hospital day (Table 1). There was a trend toward patients in the high-protein group being older, heavier, and taller, but these differences of means were not statistically significant $(p>0.05)$. Z-scores for weight and height indicated that ratios for both groups were lower than for National Center for Health Statistics controls. The means of serum concentrations of total protein and albumin were comparable, but there were significantly greater mean concentrations of prealbumin and retinol-binding protein in the control group than the high-protein group $(p<0.05)$. The mean values of serum IGF-I concentrations in both groups were lower than the mean value of $8.5 \mathrm{nmol} / \mathrm{L}(65 \mathrm{ng} / \mathrm{mL})$ reported for normal US children of the same age (13).

During the first 5 hospital d before the start of dietary therapy, estimates of intake of calories and protein on the regular hospital diet were made. Both groups were comparable, with mean $\pm \mathrm{SD}$ of calorie intakes in $\mathrm{kcal} / \mathrm{kg} / \mathrm{d}$ of $128 \pm 16$ for controls and 118 \pm 15 for the high-protein group. Estimated mean \pm SD of intakes of protein in $\mathrm{g} / \mathrm{kg} / \mathrm{d}$ was $2.1 \pm 0.2$ for controls and $2.0 \pm 0.4$ for the high-protein group.

Effects of dietary intervention on growth and serum proteins. All patients completed $21 \mathrm{~d}$ of dietary intervention except for two each in the control and the high-protein groups who completed 16 and $18 \mathrm{~d}$ each. The mean $\pm \mathrm{SD}$ of estimated daily
Table 1. Characteristics of patients before treatment in groups that received control diet and high-protein diet*

\begin{tabular}{lcc}
\hline & $\begin{array}{c}\text { Control diet } \\
(n=10)\end{array}$ & $\begin{array}{c}\text { High-protein diet } \\
(n=12)\end{array}$ \\
\hline Age (mo) & $31.7 \pm 9.3$ & $36.3 \pm 6.7$ \\
Range & $(24-48)$ & $(24-48)$ \\
Gender (no. male/female) & $7 / 3$ & $10 / 2$ \\
Shigella species (no. with) & & \\
$\quad$ Dysenteriae 1 & 5 & 8 \\
$\quad$ Flexneri & 5 & 3 \\
$\quad$ Sonnei & 0 & 1 \\
Stool weight/24 h (g) & $304 \pm 196$ & $278 \pm 110$ \\
Weight (kg) & $10.3 \pm 2.0$ & $10.8 \pm 1.4$ \\
Height (cm) & $85.0 \pm 8.4$ & $87.5 \pm 5.6$ \\
Weight for age $\dagger$ & $-2.4 \pm 1.0$ & $-2.3 \pm 0.8$ \\
Weight for height $\dagger$ & $-1.6 \pm 0.6$ & $-1.6 \pm 0.7$ \\
Height for age $\dagger$ & $-1.7 \pm 1.6$ & $-1.7 \pm 1.0$ \\
Mid-upper-arm circumfer- & $13.1 \pm 0.7$ & $13.3 \pm 1.0$ \\
$\quad$ ence (cm) & & \\
Triceps skinfold thickness & $6.4 \pm 1.2$ & $6.4 \pm 1.3$ \\
$\quad$ (mm) & & \\
Serum concentrations $\dagger$ & & \\
$\quad$ Total protein (g/L) & $68.8 \pm 4.2$ & $66.9 \pm 4.4$ \\
Albumin (g/L) & $39.6 \pm 3.7$ & $38.6 \pm 4.9$ \\
Prealbumin (mg/dL) & $12.1 \pm 3.4$ & $9.3 \pm 3.1$ \\
Retinol-binding protein & $1.65 \pm 0.62$ & $1.08 \pm 0.33$ \\
$\quad$ (mg/dL)§ & & \\
IGF-I (ng/mL)§ & $31.9 \pm 19.6$ & $24.0 \pm 26.3$ \\
\hline
\end{tabular}

$*$ Values are means $\pm \mathrm{SD}$, or as indicated.

$\dagger$ Values are Z-scores calculated from National Center for Health Statistics data.

$\ddagger$ Normal values for total protein in children, $62-80 \mathrm{~g} / \mathrm{L}$; albumin after infancy, $35-50 \mathrm{~g} / \mathrm{L}$; prealbumin after 1 y of age, $10-40 \mathrm{mg} / \mathrm{dL}$; and retinol-binding protein in children $2-10 \mathrm{y}$ old, $2.2-4.5 \mathrm{mg} / \mathrm{dL}$ (14). Normal range of IGF-I from birth to $6 \mathrm{y}, 30-141 \mathrm{ng} / \mathrm{mL}$ (13).

$\S$ For conversion to SI units, multiply $\mathrm{mg} / \mathrm{dL}$ values of prealbumin and retinol-binding protein by 0.01 to obtain $\mathrm{g} / \mathrm{L}$. For IGF-I, multiply $\mathrm{ng} / \mathrm{mL}$ values by 0.1307 to obtain $\mathrm{nmol} / \mathrm{L}$.

average caloric intake for the children fed the control diet was $152 \pm 9 \mathrm{kcal} / \mathrm{kg} / \mathrm{d}$ and for children fed the high-protein diet, 140 $\pm 6 \mathrm{kcal} / \mathrm{kg} / \mathrm{d}$. The mean $\pm \mathrm{SD}$ of estimated daily average protein intake was $2.34 \pm 0.23 \mathrm{~g} / \mathrm{kg} / \mathrm{d}$ for children fed the control diets and $5.47 \pm 0.25 \mathrm{~g} / \mathrm{kg} / \mathrm{d}$ for children fed the high-protein diets.

Children who were fed high-protein diets showed greater mean increases in body weight and height than children fed the isocaloric control diet (Table 2 ), but only the difference in weight gain was statistically significant $(p<0.025)$. Greater increases in mean concentrations of serum proteins were measured in children fed high-protein diets than in children fed control diets, with statistically significant differences demonstrated for total protein, prealbumin, and retinol-binding protein $(p<0.05$; Table 2). The increases in serum IGF-I were such that the mean increase $\pm \mathrm{SD}$ in the control group of $16.7 \pm 9.2 \mathrm{nmol} / \mathrm{L}(128$ $\pm 70 \mathrm{ng} / \mathrm{mL}$ ) placed this group at the upper limits of the normal range for normal US children of the same age. The mean increase in the children fed the high-protein diet of $39.0 \pm 16.2 \mathrm{nmol} / \mathrm{L}$ $(298 \pm 124 \mathrm{ng} / \mathrm{mL})$ placed them well above the normal range. The magnitude of the increase in IGF-I concentration was greater in the children fed the high-protein diet $(p<0.01$; Table 2$)$.

\section{DISCUSSION}

Children fed the high-protein diet showed significantly greater increases in weight and mid-upper-arm circumference during the feeding period than children fed the control diet. Similarly, there was a trend toward greater increases in height and skinfold thickness in the group receiving the high-protein diet. Concentrations of total serum protein, albumin, prealbumin, and retinol- 
Table 2. Increases in nutritional determinants and serum concentrations of proteins and IGF-I between pretreatment measurements and end of 21 d of dietary intervention in children who received control diets or high-protein diets*

\begin{tabular}{lccc}
\hline & $\begin{array}{c}\text { Control diet } \\
(n=10)\end{array}$ & $\begin{array}{c}\text { High-protein diet } \\
(n=12)\end{array}$ & $p$ value \\
\hline Weight $(\mathrm{kg})$ & $0.76 \pm 0.45$ & $1.23 \pm 0.36$ & $<0.025$ \\
Height $(\mathrm{cm})$ & $0.74 \pm 0.40$ & $0.83 \pm 0.42$ & $\mathrm{NS}$ \\
Weight for age $\dagger$ & $0.5 \pm 0.4$ & $0.8 \pm 0.2$ & $<0.01$ \\
Weight for height $\dagger$ & $0.5 \pm 0.5$ & $0.9 \pm 0.3$ & $<0.05$ \\
Height for age $\dagger$ & $0.02 \pm 0.1$ & $0.04 \pm 0.1$ & $\mathrm{NS}$ \\
Mid-upper-arm circum- & $0.96 \pm 0.43$ & $1.40 \pm 0.42$ & $<0.05$ \\
$\quad$ & & \\
$\quad$ ference $(\mathrm{cm})$ & & & $\mathrm{NS}$ \\
Triceps skinfold thick- & $1.28 \pm 0.65$ & $1.60 \pm 0.82$ & \\
$\quad$ ness (mm) & & & \\
Serum concentrations & & & \\
$\quad$ Total protein (g/L) & $3.05 \pm 2.63$ & $6.88 \pm 4.35$ & $<0.05$ \\
$\quad$ Albumin $(\mathrm{g} / \mathrm{L})$ & $3.86 \pm 3.28$ & $5.23 \pm 5.34$ & $\mathrm{NS}$ \\
$\quad$ Prealbumin $(\mathrm{mg} / \mathrm{dL}) \ddagger$ & $3.80 \pm 6.92$ & $14.20 \pm 6.74$ & $<0.01$ \\
$\quad$ Retinol-binding pro- & $1.02 \pm 0.86$ & $2.67 \pm 1.37$ & $<0.01$ \\
$\quad$ tein $(\mathrm{mg} / \mathrm{dL}) \ddagger$ & & & \\
IGF-I (ng/mL) $\$$ & $128 \pm 70$ & $298 \pm 124$ & $<0.01$ \\
\hline
\end{tabular}

$*$ Values are means $\pm \mathrm{SD}$

$\uparrow$ Values are Z-scores calculated from National Center for Health Statistics data.

$\ddagger$ For conversion to SI units, multiply $\mathrm{mg} / \mathrm{dL}$ values of prealbumin and retinol-binding protein by 0.01 to obtain $\mathrm{g} / \mathrm{L}$. For IGF-I, multiply $\mathrm{ng} / \mathrm{mL}$ values by 0.1307 to obtain $\mathrm{nmol} / \mathrm{L}$.

binding protein also increased more in the children fed the highprotein diet than in those fed the control diet. These results showing beneficial effects of a diet high in both caloric value and protein content on catch-up growth and serum proteins are consistent with dietary studies of malnutrition in Thai children (15). The lesser degree of malnutrition among our patients, though they were not as severely malnourished as the Thai children, is probably more characteristic of children in developing countries. Although the high-protein diet did not produce significantly more height gain, it is possible that a longer period of dietary intervention or follow-up studies after hospital discharge would reveal significant differences.

We measured serum concentrations of IGF-I, a mediator of the growth-promoting actions of growth hormone that is responsive to repletion of calories and protein in malnourished patients (8), to determine whether this peptide might be involved in the faster growth of the children fed high-protein diets. Concentrations of IGF-I of both groups of Bangladeshi children before dietary intervention were lower than those for normal US children, indicating prior malnutrition or short-term nutrient deprivation due to their Shigella infection (16). IGF-I concentrations in children fed both diets rose significantly above normal values, indicating an over-response similar to that described in malnourished adults during nutritional repletion and return to positive nitrogen balance. (17). The greater increases in IGF-I observed in children fed the high-protein diet confirms that this mediator of growth hormone action is responsive to dietary protein $(8,18)$. The magnitude of the increase in IGF-I may also reflect the sensitivity of children to sufficiency of dietary protein, because the serum IGF-I concentration in young rats is exquisitely sensitive to dietary protein restriction (19).

The mechanisms for the dramatic rise in serum IGF-I during dietary repletion are not defined by this study. It is highly probable, however, that there is an increase in IGF-I synthesis, because diet restriction in rats reduces IGF-I mRNA $(20,23)$, and refeeding leads to restoration of serum IGF-I peptide concentrations in rats (24) and humans (17). The "overshoot" in serum IGF-I might indicate a measure of IGF-I resistance, as it has been shown that protein-restricted rats do not undergo somatic growth in response to administration of IGF-I or growth hormone (25). It is conceivable, therefore, that refeeding improved the synthetic capacity for IGF-I more rapidly than it improved tissue response to IGF-I. Against the possibility of IGF-I resistance, but not excluding it, is the finding that weight gain and statural growth occurred during the refeeding period. The serum concentrations of IGF-I are regulated by several binding proteins, and at least three of these peptides are modulated by nutritional status (26). IGFBP-III is a likely candidate for change relevant to the events we have observed, because IGFBP-III, the major carrier of IGF-I in serum, is reduced in diet restriction (27). A dramatic increase in this peptide during refeeding could facilitate the rise observed in IGF-I. Studies of the changes in IGFBP in our patients are in progress and will be the subject of a future report.

Increased protein in the diet of patients recovering from shigellosis may also have a beneficial effect on the repair of injured intestinal mucosa. Patients with acute shigellosis are known to have protein-losing enteropathy (28) and sometimes show extensive inflammatory destruction of intestinal mucosa (29). Studies to measure intestinal clearance of $\alpha$-1-antitrypsin before and after dietary intervention will be needed to detect any improvement in the healing of the intestinal mucosa due to treatment.

On the other hand, efforts to promote protein synthesis and growth during recovery from shigellosis may be opposed by the acute phase reaction of inflammation. During acute inflammatory reactions, the liver shifts to synthesizing acute-phase reactant proteins, such as C-reactive protein, and decreases synthesis of other proteins, such as albumin and prealbumin (30). Thus, the hypoalbuminemia and impaired growth rates associated with acute infections may be, to some extent, refractory to dietary treatment that is begun while inflammation is active.

In our patients, the serum concentrations of prealbumin and retinol-binding protein were more responsive to protein in the diet than was the albumin concentration. This may be explained by the fact that the former proteins have a high turnover rate, with half-lives of $1.9 \mathrm{~d}$ for prealbumin and $10 \mathrm{~h}$ for retinolbinding protein. In contrast, albumin has a half-life of 12-21 d (31). In Egyptian children with kwashiorkor, the serum concentrations of prealbumin and retinol-binding protein also increased significantly 2-4 wk after beginning dietary treatment (32), and in premature infants the serum prealbumin was a more sensitive indicator of nutritional intake than was serum albumin (31).

These results indicate that dietary treatment of dysentery, and perhaps other infectious diseases, in growing children should include diets plentiful in protein. The quality of the protein provided in protein-restricted normal adults has been shown to regulate the serum concentrations of IGF-I (33). It is important, therefore, to determine which protein-containing foods will promote recovery most rapidly. In this study, the bulk of the excess protein was in the form of milk, eggs, and chicken. It will be useful to determine whether more readily available and economical vegetable proteins such as those derived from legumes will achieve the same effects as the animal proteins used in this study.

\section{REFERENCES}

1. Scrimshaw NS 1977 Effect of infection on nutrient requirements. Am J Clin Nutr 30:1536-1544

2. Black RE, Brown KH, Becker S 1984 Effects of diarrhea associated with specific enteropathogens on the growth of children in rural Bangladesh. Pediatrics 73:799-805

3. Brown KH, MacLean WC 1984 Nutritional management of acute diarrhea: an appraisal of the alternatives. Pediatrics 73:119-125

4. Butler T, Speelman P, Kabir I, Banwell J 1986 Colonic dysfunction during shigellosis. J Infect Dis 154:817-824

5. Whitehead RG 1977 Protein and energy requirements of young children living in the developing countries to allow for catch-up growth after infection. Am J Clin Nutr 30:1545-1547

6. Butler T, Islam MR, Azad AK, Jones PK 1987 Risk factors for development of the hemolytic-uremic syndrome during shigellosis: role of antimicrobial treatment. J Pediatr 110:894-897

7. Coward WA, Fiorotto M 1979 The pathogenesis of edema in kwashiorkor: the role of plasma proteins. Proc Nutr Soc 38:51-59

8. Isley WL, Underwood LE, Clemmons DR 1983 Dietary components that 
regulate somatomedin- $\mathrm{C}$ concentrations in humans. $\mathrm{J}$ Clin Invest 71:175182

9. Jelliffe DB 1966 Assessment of nutritional status of the community with special reference to field surveys in developing regions of the world. WHO Monograph Series No. 53. World Health Organization, Geneva, pp 221-232

10. Henry JB 1984 Todd-Sanford-Davidson Clinical Diagnosis and management by Laboratory Methods, 17th Ed. WB Saunders, Philadelphia, pp 207-208

11. Barry KG, McLaurin AW, Parnell BL 1960 A practical temperature-compensated hand refractometer (the TS meter): its clinical use and application in estimation of total serum proteins. J Lab Clin Med 55:803-808

12. Davenport ML, Svoboda ME, Koerber KL, VanWyk JJ, Clemmons DR Underwood LE 1988 Serum concentrations of insulin-like growth factor-II are not changed by short-term fasting and refeeding. J Clin Endocrinol Metab 67:1231-1236

13. Underwood LE, VanWyk JJ 1991 Normal and aberrant growth. In: Foster DW, Wilson JD (eds) William's Textbook of Endocrinology, 8th Ed. WB Saunders, Philadelphia, pp 1079-1138

14. Behrman RE, Vaughan VC III, Nelson WE (eds) 1987 Nelson Textbook of Pediatrics, 13th Ed. WB Saunders, Philadelphia, pp 1535-1556

15. Varma RN, Suskind LL, Thanangkul O, Suskind RM 1984 Catch-up growth in malnourished children. In: Lebenthal $\mathrm{E}$ (ed) Chronic Diarrhea in Children. Verey/Raven Press, New York, pp 209-220

16. Clemmons DR, Klibanski A, Underwood LE, McArthur JW, Ridgway EC, Beitins IZ, VanWyk JJ 1981 Reduction of plasma immunoreactive somatomedin-C during fasting in humans. J Clin Endocrinol Metab 53:12471250

17. Clemmons DR, Underwood LE, Dickerson RN, Brown RO, Hak LJ, MacPhee RD, Heizer WD 1985 Use of plasma somatomedin-C/insulin-like growth factor-I measurements to monitor the response to nutritional repletion in malnourished patients. Am J Clin Nutr 41:191-198

18. Isley WI, Underwood LE, Clemmons DR 1984 Changes in plasma somatomedin- $C$ in response to ingestion of diets of variable protein and energy content. J Parenter Enteral Nutr 8:407-411

19. Fliesen T, Maiter D, Gerard G, Underwood LE, Maes M, Ketelslegers J-M 1989 Reduction of serum insulin-like growth factor-I by dietary protein restriction is age dependent. Pediatr Res 26:415-419

20. Emler CA, Schalch DS 1987 Nutritionally induced changes in hepatic insulinlike growth factor-I (IGF-I) gene expression in rats. Endocrinology 120:832834
21. Moats-Staats BM, Brady JL, Underwood LE, D'Ercole AJ 1989 Dietary protein restriction in artificially reared neonatal rats causes a reduction of insulinlike growth factor-I (IGF-I) gene expression. Endocrinolgy 125:2368-2374

22. VandeHaar ML, Moats-Staats BM, Davenport ML, Walker JL, Ketelslegers JM, Sharma BK, Underwood LE 1991 Reduced serum concentrations of insulin-like growth factor-I (IGF-I) in protein-restricted growing rats are accompanied by reduced IGF-I messenger RNA levels in liver and skeletal muscle. J Endocrinol 130:305-312

23. Straus DS, Takemot CD 1990 Effect of dietary protein deprivation on insulinlike growth factor-I and II, IGF binding protein- 2 and serum albumin gene expression in rat. Endocrinology 127:1849-1860

24. Maes M, Underwood LE, Ketelslegers J-M 1983 Plasma somatomedin-C in fasted and refed rats: close relationship with changes in liver somatogenic (GH) but not lactogenic (PRL) binding sites. J Endocrinol 97:243-252

25. Thissen JP, Underwood LE, Maiter D, Maes M, Clemmons DR, Ketelslegers J-M 1991 Failure of IGF-I infusion to promote growth in protein-restricted rats despite normalization of serum IGF-I concentrations. Endocrinology 128:885-890

26. Clemmons DR, Underwood LE 1991 Nutritional regulation of IGF-I and IGF binding proteins. Annu Rev Nutr 11:393-412

27. Clemmons DR, Thissen JP, Maes M, Ketelslegers J-M, Underwood LE 1989 Insulin-like growth factor-I (IGF-I) infusion into hypophysectomized or protein-deprived rats induces specific IGF binding proteins in serum. Endocrinology 125:2967-2972

28. Sarker SA, Wahed MA, Rahaman MM, Alam AN, Islam A, Jahan F 1986 Persistent protein losing enteropathy in post measles diarrhoea. Arch Dis Child 61:739-743

29. Butler T, Dunn D, Dahms B, Islam M 1989 Causes of death and the histopathologic findings in fatal shigellosis. Pediatr Infect Dis J 8:767-772

30. Dickson PW, Howlett GJ, Schreiber G 1987 Metabolism of prealbumin in rats and changes induced by acute inflammation. Eur J Biochem 129:289-293

31. Moskowitz SR, Pereiva G, Spitzer A, Heaf L, Amsel J, Watkins JB 1983 Prealbumin as a biochemical marker of nutritional adequacy in premature infants. J Pediatr 102:749-753

32. Smith FR, Goodman DS, Zaklama MS, Gabr MK, Maraghy SE, Patwardhan VN 1973 Serum vitamin A, retinol-binding protein and prealbumin concentrations in protein-calorie malnutrition. Am J Clin Nutr 26:973-981

33. Clemmons DR, Seek M, Underwood LE 1985 Supplementary essential amino acids augment the somatomedin-C/insulin-like growth factor-I response to refeeding after fasting. Metabolism 34:391-395 